\title{
Response to 'Infliximab therapy increases body fat mass in early rheumatoid arthritis independently of changes in disease activity and levels of leptin and adiponectin: a randomized study over 21 months'
}

\author{
Miguel A Gonzalez-Gay ${ }^{+1}$, Carlos Gonzalez-Juanatey², Jose A Miranda-Filloy ${ }^{3}$, Javier Martinㄴ, Maria T Garcia-Unzueta \\ and Javier Llorca*6,7
}

See related research by Engvall et al., http://arthritis-research.com/content/12/5/R197

We read with great interest the study by Engvall and colleagues [1] in a recent issue of Arthritis Research $\mathcal{E}$ Therapy. The study showed that anti-tumor necrosis factor-alpha (anti-TNF- $\alpha$ ) infliximab therapy is associated with an increase of body fat mass in early rheumatoid arthritis (RA) independently of changes in disease activity and levels of leptin and adiponectin.

With respect to this, we have prospectively followed a cohort of patients who had RA refractory to conventional disease-modifying antirheumatic drugs, including methotrexate, and who, owing to disease severity, underwent anti-TNF- $\alpha$-infliximab therapy. Among them, a subgroup of 33 consecutive RA patients who were on periodical treatment with infliximab and who agreed to participate in the study was assessed to determine the short-term effect of this drug on insulin resistance, ghrelin, and adipokine profile. Besides noting a dramatic improvement of insulin resistance following infliximab administration [2], we observed that, upon administration of this drug, serum ghrelin concentrations (in picograms per milliliter) increased significantly $(896.1 \pm 314.8$, median 861.2, interquartile range (IQR) 700.5 to 879.9 before infliximab at time 0 (baseline) and $976.3 \pm 373.0$, median 905.8, IQR 752.6 to $1,152.8$ after infliximab infusion at 120 minutes; $P<0.001$ ) and that increases in ghrelin concentrations were associated with reductions in

\footnotetext{
${ }^{\dagger}$ MAG-G and JL share senior authorship.

*Correspondence: Ilorcaj@unican.es

${ }^{6}$ Division of Epidemiology and Computational Biology, School of Medicine, University of Cantabria, Avda. Herrera Oria s/n. 39011-Santander, Spain Full list of author information is available at the end of the article
}

P-selectin concentrations $(r=-0.513 ; P=0.002)$ [3]. However, ghrelin concentrations were not related to the DAS28 (disease activity score using 28 joint counts), the mean erythrocyte sedimentation rate (ESR), and Creactive protein (CRP) from disease diagnosis or the ESR, platelet count, CRP, or cumulative prednisone dose at the time of the study [3]. Moreover, we observed a significant correlation between leptin levels and body mass index [4].

Apart from stimulating growth hormone production, ghrelin regulates energy homeostasis through increasing food intake and decreasing fat utilization, leading to increased adiposity through growth hormone-independent mechanisms [5]. Ghrelin is further associated with metabolic syndrome features, and ghrelin administration has beneficial effects not only on cachexia in patients with heart failure and chronic obstructive pulmonary disease but also on insulin sensitivity in overweight patients and endothelial dysfunction in patients with metabolic syndrome [6]. Additionally, ghrelin has potent anti-inflammatory effects, including the inhibition of proinflammatory cytokine production by $\mathrm{T}$ lymphocytes and monocytes within the immune system and human endothelial cells [7]. Besides noting the rapid decrease of P-selectin, a biomarker of endothelial dysfunction [8], we observed a rapid and significant improvement of endothelial function following infliximab administration in these patients [9].

According to our observations, anti-TNF- $\alpha$ therapy increases serum levels of ghrelin. Since ghrelin has antiinflammatory effects, increased levels presumably would be additive to the efficacious actions of infliximab [3].

Metabolic syndrome features are independently associated with atherosclerosis in RA [10]. However, in our 
series of patients with severe RA, in contrast to what was reported in non-RA subjects, metabolic syndrome features were not related to ghrelin concentrations [3]. It is possible that improvement of ghrelin metabolism through inhibition of cytokine production attenuates the cachexia in patients with RA. Additionally, in our series, we observed a significant increase of body mass index when values obtained before the onset of infliximab therapy were compared with those observed after 2 years of infliximab therapy (unpublished observations).

Considering all of these observations, we feel that, in patients with severe RA, the TNF- $\alpha$ blockade may improve the impaired production of ghrelin, a hormone that is implicated in RA-associated cachexia. This effect may lead to an increase of body mass index in RA patients undergoing TNF- $\alpha$ antagonist therapy.

Abbreviations

CRP, C-reactive protein; ESR, erythrocyte sedimentation rate; IQR, interquartile range; RA, rheumatoid arthritis; TNF-a, tumor necrosis factor-alpha.

\section{Competing interests}

The authors declare that they have no competing interests.

\section{Acknowledgments}

This work was supported by two grants from Fondo de Investigaciones Sanitarias, PI06-0024 and PS09/00748 (Spain), and in part by RETICS Program grant RD08/0075 (RIER) from Instituto de Salud Carlos III (ISCIII).

\section{Author details}

'Division of Rheumatology, Hospital Universitario Marqués de Valdecilla, Avenida de Valdecilla s/n, 39008-Santander, IFIMAV, Santander, Spain. ²Division of Cardiology, Hospital Xeral-Calde, c) Dr. Ocha s/n, 27004-Lugo, Spain. ${ }^{3}$ Division of Rheumatology, Hospital Xeral-Calde, c) Dr. Ocha s/n, 27004-Lugo, Spain. ${ }^{4}$ Instituto de Parasitología y Biomedicina López-Neyra, Consejo Superior de Investigaciones Científicas (C.S.I.C.), Parque Tecnológico de Ciencias de la Salud, Avda. del Conocimiento, s/n, 18100 Armilla, Granada, Spain. ${ }^{5}$ Endocrinology Research Unit, Hospital Universitario Marqués de Valdecilla, Avenida de Valdecilla s/n, 39008-Santander, IFIMAV, Santander, Spain. ${ }^{6}$ Division of Epidemiology and Computational Biology, School of Medicine, University of Cantabria, Avda. Herrera Oria s/n. 39011 -Santander, Spain. ${ }^{7} \mathrm{CIBER}$ Epidemiología y Salud Pública (CIBERESP), IFIMAV, Spain

Published: 27 April 2011

\section{References}

1. Engvall I-L, Tengstrand B, Brismar K, Hafström I: Infliximab therapy increases body fat mass in early rheumatoid arthritis independently of changes in disease activity and levels of leptin and adiponectin: a randomized study over 21 months. Arthitis Res Ther 2010, 12:R197.

2. Gonzalez-Gay MA, De Matias JM, Gonzalez-Juanatey C, Garcia-Porrua C, Sanchez-Andrade A, Martin J, Llorca J: Anti-tumor necrosis factor-alpha blockade improves insulin resistance in patients with rheumatoid arthritis. Clin Exp Rheumatol 2006, 24:83-86.

3. Gonzalez-Gay MA, Garcia-Unzueta MT, Berja A, Vazquez-RodriguezTR, Gonzalez-Juanatey C, de Matias JM, Martin J, Dessein PH, Llorca J: Antitumour necrosis factor alpha therapy modulates ghrelin in patients with severe rheumatoid arthritis. Ann Rheum Dis 2008, 67:1644-1646.

4. Gonzalez-Gay MA, Garcia-Unzueta MT, Berja A, Gonzalez-Juanatey C, Miranda-Filloy JA, Vazquez-Rodriguez TR, de Matias JM, Martin J, Dessein PH, Llorca J: Anti-TNF-alpha therapy does not modulate leptin in patients with severe rheumatoid arthritis. Clin Exp Rheumatol 2009, 27:222-228.

5. Otto B, Cuntz U, Fruehauf E, Wawarta R, Folwaczny C, Riepl RL, Heiman ML, Lehnert $P$, Fichter $M$, Tschöp M: Weight gain decreases elevated plasma ghrelin concentrations of patients with anorexia nervosa. Eur J Endocrinol 2001, 145:669-673.

6. Nagaya N, Kojima M, Kangawa K: Ghrelin, a novel growth hormonereleasing peptide, in the treatment of cardiopulmonary-associated cachexia. Intern Med 2006, 45:127-134.

7. Li WG, Gavrila D, Liu X, Wang L, Gunnlaugsson S, Stoll LL, McCormick ML, Sigmund CD, Tang C, Weintraub NL: Ghrelin inhibits proinflammatory responses and nuclear factor-kappaB activation in human endothelial cells. Circulation 2004, 109:2221-2226.

8. Gonzalez-Gay MA, Garcia-Unzueta MT, De Matias JM, Gonzalez-Juanatey C, Garcia-Porrua C, Sanchez-Andrade A, Martin J, Llorca J: Influence of anti-TNFalpha infliximab therapy on adhesion molecules associated with atherogenesis in patients with rheumatoid arthritis. Clin Exp Rheumatol 2006, 24:373-379.

9. Gonzalez-Juanatey C, Testa A, Garcia-Castelo A, Garcia-Porrua C, Llorca J, Gonzalez-Gay MA: Active but transient improvement of endothelial function in rheumatoid arthritis patients undergoing long-term treatment with anti-tumor necrosis factor alpha antibody. Arthritis Rheum 2004, 51:447-450.

10. Dessein PH, Tobias M, Veller MG: Metabolic syndrome and subclinical atherosclerosis in rheumatoid arthritis. J Rheumato/ 2006, 33:2425-2452.

\section{doi:10.1186/ar3301}

Cite this article as: Gonzalez-Gay MA, et al:: Response to 'Infliximab therapy increases body fat mass in early rheumatoid arthritis independently of changes in disease activity and levels of leptin and adiponectin: a randomized study over 21 months'. Arthritis Research \& Therapy 2011, 13:404. 